IRSH 60 (2015), pp. 73-95 doi:10.1017/S00208590I 50000 I 2

(C) 2015 Internationaal Instituut voor Sociale Geschiedenis

SUGGESTIONS AND DEBATES

\title{
What Is Agrarian Labour? Contrasting Indigo Production in Colonial India and Indonesia*
}

\author{
WILLEM VAN SCHEN DEL \\ International Institute of Social History \\ PO Box 2169, I000 CD Amsterdam, The Netherlands
}

E-mail: h.w.vanschendel@uva.nl; www.willemvanschendel.com.

\begin{abstract}
AвSTRACT: In scholarly writings, the term “agrarian labour” is used variously. It can refer to a very specific set of productive activities - the cultivation of crops and animal husbandry - but it can also have the much broader connotation of rural or non-urban labour. These different uses can be confusing, especially in comparative research. This paper starts from the French comparative agriculture school and its conceptualization of three nested scales of analysis - the "cropping system", the "activity system", and the "agrarian system". It tests these ideas in a comparison of labour employed in the production of indigo dye in two colonial systems (British India and the Dutch East Indies). The article concludes that this approach helps counteract monocausal explanations of labour relations in terms of agro-environmental determinants, the force of colonial capitalism, or local work cultures. It also promotes agriculture-sensitive readings of social transformations by comparing social orders that comprise both agricultural and non-agricultural labour relations.
\end{abstract}

Social scientists have developed a range of analytical terms to study human life in rural areas. Often they use these terms without clearly defining them, which can lead to confusion. In this article I consider the term "agrarian". Widely used, its meaning tends to vary markedly. For some, it denotes a specific set of productive activities - the cultivation of crops and animal husbandry - and is equivalent to farming or agriculture. For others, "agrarian" is much broader, equalling rural or non-urban. Thus it is possible

* I would like to thank participants of the Conference on the Global History of Agarian Labor Regimes 1750-2000 (Weatherhead Initiative in Global History, Harvard University, April 2013), the research groups "Plants, People and Work" (International Institute of Social History), and "Moving Matters" (University of Amsterdam), three anonymous readers for their comments, and Kathinka Sinha-Kerkhoff and Masoom Reza for their help in locating source material. 
to speak of "agrarian structures", "agrarian unrest", and "agrarian societies" - and here the spatial and social indices (the countryside, the peasantry) tend to be more significant than the reference to crop production.

Agronomists and agricultural economists stay close to the narrow meaning of agrarian, whereas many historians, anthropologists, and geographers prefer the broader connotation - and it is in these fields that misunderstandings are most likely to occur. Clarity about the term is of special importance to comparatists because they combine information across time periods, cultures, and languages. It matters how we apply "agrarian" to these contexts, not least because this English term may not have exact referents in other cultures, languages, and periods.

\section{THE “AGRARIAN SYSTEM”}

We could discard the term "agrarian" on the ground that it confounds rather than illuminates. But we can also harness it for comparative purposes, and that is what I wish to do here. Historical change in rural areas has long been predicated on changes in agriculture, although agriculture has never been the sole mover. The term agrarian can be useful in an approach to historical rural change that takes its cue from agricultural activities without restricting itself to them.

I would like to demonstrate this by employing the ideas of the French school of "comparative agriculture". This approach - obviously not the only one to explore ways to apply the term agrarian - is of special interest because its contribution has received relatively little attention in anglophone conceptual debates. The purpose of this article is to draw attention to these ideas by showing how they can help in comparing two historical cases.

The comparative agriculture school (and its core concept, the "agrarian system") developed among French geographers, agronomists, and agricultural economists after World War II. It flourished in the I970s and I980s, when specialized departments sprang up in various research institutes. ${ }^{\mathrm{I}}$ It continues to be important in francophone studies that focus

I. A major centre promoting the comparative agriculture approach was INA P-G (Institut National Agronomique Paris-Grignon), which, in 2007, merged with two other research institutes to become AgroParisTech (Paris Institute of Technology for Life, Food and Environmental Sciences). From 1974 Marcel Mazoyer, a leading theorist of this approach, was a professor of comparative agriculture and agrarian development at INA P-G; other prominent researchers were Marc Dufumier and Hubert Cochet. The Comparative Agriculture approach also led other French research centres to establish departments, notably CIRAD (Centre de Coopération Internationale pour la Recherche Agronomique sur le Développement - Department of Agrarian Systems), and INRA (Institut National de Recherche Agronomique - Unit of Comparative Agriculture and Agrarian Development). Comparative agriculture research at these institutions was strengthened by collaboration with colleagues at several other research centres, notably INSEE (Institut National des Statistiques et des Études Économiques), ORSTOM (Office 
on understanding interactions between nature and society in rural regions, on theorizing the interface between the biophysical and the socio-economic, and on treating landscape not merely as a space but as a social act. ${ }^{2}$

In the I960s geographers began scrutinizing these interactions in what became known as the terroir approach. For them, a terroir was "an expanse of land appropriated, managed and used by the group of people that resides on it and draws from it their means of existence". ${ }^{3}$ It represented "the socio-natural beritage of a group in which its internal social organization and pattern of resource use were inscribed in the landscape". ${ }^{4}$

The idea of the "agrarian system" expanded this reasoning both temporally and spatially. No longer engrossed in regional heritages, its proponents began to explore the longue durée of agricultural transformations, inter-regional connections, social divisions of labour, and linkages between agriculture, trade, and industry. Among the most influential statements of this new comparative agriculture school is that of Marcel Mazoyer and Laurence Roudart. According to them, the "agrarian system" is a concept that makes it possible to: (I) comprehend the complexity of each form of agriculture by the methodical analysis of its structure and its functioning; (2) classify the innumerable agricultural forms identifiable in the past or observable today in a limited number of systems; (3) represent the continual transformations in a region of the world as a succession of distinct systems; and (4) explain the geographical diversity of agriculture in a given epoch. ${ }^{5}$

de la Recherche Scientifique et Technique d'Outre-Mer) and IRAM (Institut de Recherches et d'Aménagement des Méthodes de Développement). An introduction to the institutional anchoring of the comparative agriculture school can be found in Marc Dufumier, "Agriculture comparée et développement agricole", Revue Tiers Monde, I9I (2007), pp. 6i I-626.

2. For overviews, see Hubert Cochet, "The Système Agraire Concept in Francophone Peasant Studies", Geoforum, 43 (2012), pp. I28-136; Hubert Cochet, Sophie Devienne, and Marc Dufumier, "L'agriculture comparée, une discipline de synthèse?", Économie rurale, 297-298 (2007), pp. 99-I I 2; and Philippe Jouve, "Quelques réflexions sur la spécificité et l'identification des systèmes agraires", Les Cahiers de la Recherche Développement, 20 (1988), pp. 5-16.

3. Gilles Sautter and Paul Pélissier, "Pour un atlas des terroirs africains: Structure-type d'une étude de terroir", L'Homme, 4 (1964), pp. 56-72, 57. All translations are mine.

4. Thomas J. Bassett, Chantal Blanc-Pamard, and Jean Boutrais, "Constructing Locality: The Terroir Approach in West Africa", Africa: The Journal of the International African Institute, 77 (2007), pp. 104-1 29, I 23 (emphasis in the original).

5. Marcel Mazoyer and Laurence Roudart, A History of World Agriculture: From the Neolithic Age to the Current Crisis (London, 2006), p. 5I. In an earlier formulation Mazoyer had stated that the "agrarian system" "encompasses the agro-ecosystem and its transformations over time; production tools, labor force, and resulting artificialization (i.e. anthropogenic impacts on the land); the social division of labor among farmers, artisans and industrial actors, and the subsequent agricultural surplus and its redistribution; exchange and trade relationships, ownership relationships and power relationships; and, finally, the ensemble of ideas and institutions that ensure social reproduction"; Marcel Mazoyer, Dynamique des Systèmes Agraires. Rapport de synthèse présenté au Comité des systèmes agraires (Paris, 1987), paraphrased in Cochet, "The Système Agraire Concept", p. I 30. 


\begin{tabular}{|c|c|c|c|}
\hline & \multicolumn{2}{|c|}{ AGRARIAN SYSTEM } & \\
\hline & $\begin{array}{l}\text { PRODUCTION SYSTEM } \\
\text { (FARMING SYSTEM)/ } \\
\text { ACTIVITY SYSTEM }\end{array}$ & 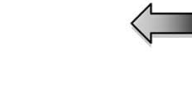 & \\
\hline & $\begin{array}{l}\text { CROPPING SYSTEM/ } \\
\text { LIVESTOCK SYSTEM }\end{array}$ & & \\
\hline $\begin{array}{l}\text { Level of } \\
\text { analysis }\end{array}$ & Plot/herd or flock & $\begin{array}{l}\text { Farm/Production } \\
\text { Unit }\end{array}$ & Village/Region/Nation \\
\hline $\begin{array}{l}\text { Type of } \\
\text { analysis }\end{array}$ & $\begin{array}{l}\text { Agronomic/Ecological } \\
\text { (bio-technological) }\end{array}$ & $\begin{array}{l}\text { Agro-socio- } \\
\text { economic }\end{array}$ & $\begin{array}{l}\text { Agro-geographic and } \\
\text { socio-economic }\end{array}$ \\
\hline
\end{tabular}

Figure I. Nested scales of analysis, after Cochet. Cochet, "The Système Agraire Concept", p. 133.

To substantiate these claims the comparative agriculture school employs a systems analysis. It is based on the idea of nested scales of analysis and suggests that the historical relationship between a society and the land it exploits can be understood by looking at three interdependent systems. ${ }^{6}$ Hubert Cochet represents the nested nature of these three systems as in Figure I above. ${ }^{7}$

The first scale of analysis is the "cropping system". It is concerned purely with the environmental and agronomic conditions underlying the cultivation of crops on a plot or group of plots. ${ }^{8}$ The "cropping system" is plot-oriented and relates to human-plant interactions. The second system

6. Although scales are often assumed to be vertically structured, there is no need to think of the nested nature of these three systems in this manner; it may be more useful to conceive of them as spatially embracing each other. For a discussion of dominant assumptions about scale as hierarchical and a call to adopt a "flat ontology", see Sally A. Marston, John Paul Jones, III, and Keith Woodward, "Human Geography without Scale", Transactions of the Institute of British Geographers, NS 30 (2005), pp. 416-432; and comments in NS 3I (2006), pp. 238-25 I, 399-306; and NS 32 (2007), pp. I06-I I I, I I6-I 25, 264-276.

7. For a visual representation of the "agrarian system" that differs from this one, see Jouve, "Quelques réflexions", p. 9.

8. The "cropping system" (systeme de production) can include animal husbandry or agroforestry. See Hubert Cochet and Sophie Devienne, "Fonctionnement et performances économiques des systèmes de production agricole: une démarche à l'échelle régionale", Cabiers Agricultures, I5 (2006), pp. 578-583; Cochet, "The Système Agraire Concept". 
is the "activity system" which refers to the immediate socio-economic environment of crop production. Its focus is not on plots but on the activities of the people who produce the crops (the cultivators, the production unit). ${ }^{9}$ Cultivators are usually pluriactive: their family strategies go well beyond agriculture and can include crop processing, off-farm crafts or trading, and labour migration. ${ }^{10}$ Thus the "activity system" can transcend the local. Enveloping both the "cropping system" and the "activity system" is a third scale of analysis, and the term "agrarian" is reserved for this one. The "agrarian system" is an "organized set of relationships historically established between a specific social structure and the land being exploited". ${ }^{\text {II }}$ It encompasses the broader context in which agricultural production is embedded. Its value lies in that it provides an agriculture-sensitive understanding of society and social change, which can be applied at the regional, national, and ultimately, transnational level. ${ }^{\text {I2 }}$

\section{AGRARIAN LABOUR}

This logic of nested scales of analysis can be applied to different aspects of relationships that are historically established between a specific social structure and the land being exploited. For example, how are ownership patterns, gender relations, or labour relations linked to particular histories of transformation of the agro-ecosystem? In this article I explore one aspect, labour relations, to assess the heuristic value of the "agrariansystems" approach.

Analysing labour relations in this way allows us to make a simple distinction. First, labour put to use in the "cropping system" deals with cultivation: preparing land (ploughing, harrowing, applying fertiliser, and

9. For this reason some describe the "activity system" as the production system, or the farming system.

I0. An early treatment of this concept can be found in Jean-Marie Cellier and Jean-Claude Marquié, "Système d'activités et régulations dans l'exploitation agricole", Le Travail Humain, 43 (I980), pp. 32 I-336. For different ways of conceptualizing the "activity system", see Pierre Gasselin, Michel Vaillant, and Benjamin Bathfield, "The Activity System: A Position Paper"; Ioth European IFSA Symposium: "Producing and Reproducing Farming Systems: New Modes of Organization for the Sustainable Food Systems of Tomorrow" (Aarhus, 2012). They define the "activity system" as "a dynamic and structured set of interacting activities carried out by a social entity [that] mobilizes available resources in an agro-ecological (ecological, agronomical, environmental, etc.) and social (historical, cultural, social, economic, technical, political, institutional, etc.) specific context", p. 4.

I I. G.R. Larrère, "Considérations générales - et quasiment théoriques - sur les systèmes agraires, point de vue qui en dérive quant à l'articulation des recherches des biologistes et des économistes dans l'ATP environnement (Région des Dômes)", October 1974 (mimeo), quoted in Cochet, "The Système Agraire Concept", p. I 29.

I 2. Mazoyer, Dynamique des Systèmes Agraires; Mazoyer and Roudart, A History of World Agriculture. 
so on), caring for plants (seed preparation, sowing, weeding, watering, sheltering etc.), and gathering crops (cutting, drying, threshing, sorting, storing). As the "cropping system" is plot-oriented rather than crop-oriented, its labour dimension embraces crop succession, fallowing, and concurrent mixtures of crops (as in slash-and-burn agriculture or intercropping).

Second, labour put to use in the "activity system" includes cropping labour as well as on-farm processing of crops and preparing crops for consumption (curing, smoking, pickling, brewing, carding, and so on), and off-farm or off-season pursuits in which cultivators and their family members are involved. These are manifold, from shopkeeping to crafts, and from service to enterprise, and some of these activities may take certain family members far away from the farm.

Finally, labour put to use in the "agrarian system" includes cropping and off-farm household activities but also the labour of those who, although not cultivators themselves, make cultivation possible, or impact on cropping in one way or another. This category is boundless because ultimately cultivation is connected to all other social spheres. However, an agriculture-sensitive reading of social change may help in defining agrarian labour by focusing on those forms that are deemed to have a direct impact on, or to be directly influenced by, labour in the cropping and activity spheres. Used in this way, agrarian labour includes activities that can also be described as industrial, entrepreneurial, or administrative.

Distinguishing between these nested labour relations - cropping, activity and agrarian - helps to avoid the familiar assumption that agrarian labour is merely labour applied directly to cultivation. This is important if we wish to consider agricultural work together with associated forms of labour. In studying the diversity of agrarian labour relations, and the paths along which they changed, it is crucially important to explain how connections between labour relations transformed at these different scales.

The "agrarian-systems" approach presents a conceptual prospect of particular interest to students of labour. Its use of the metaphor of nested life spheres certainly is not unique - many other approaches seek to elucidate social complexity by invoking scale. ${ }^{\mathrm{I}}$ But its agriculturesensitive understanding of social change is unusual in labour studies, a field that continues to be fascinated by, and oriented towards, the urban and the industrial. The "agrarian-systems" approach points to the question of what we mean when we speak of agrarian labour. The open-ended nature of the largest scale - the "agrarian system" - makes it possible to incorporate into analyses of local cultivation practices various linkages with non-cropping, non-rural labour as well as with commercial and 
policy decisions in far-off locations. But this open-endedness comes with its own problems. The comparative agriculture approach does not provide ready-made procedures for assessing the impact of such distant processes and their variable effects on labour in the "cropping", "activity", and "agrarian systems". For the time being, the approach seems to be most effective when applied at the regional scale, as I shall do here. The following pages test the central idea of comparative agriculture, the "agrarian system", by comparing two colonial attempts to manipulate agrarian labour relations.

\section{EMBEDDING NEW LABOUR RELATIONS}

One way of assessing the usefulness of the concept of the "agrarian system" in understanding concrete historical circumstances is by focusing on moments of systemic change. The establishment of colonial regimes provides such a moment. This article looks at the manipulation of two sets of agrarian labour relations in colonial Asia with an eye to facilitating cash-cropping for European consumption. These attempts occurred in different colonies and yet they were connected: they involved the same crop and therefore each of them had to come to terms with the agronomic requirements of that crop. The outcomes of these attempts contrasted in many ways, however, not least because ecological conditions and preexisting labour relations differed. The article presents these contrasts and it concludes with a brief consideration of what these cases mean for our understanding of agrarian labour relations.

Around I 800 a number of local calamities coincided to shake up the world market for one of the most valuable dyestuffs - indigo. This vegetal blue substance, much sought after in Europe, was best produced in tropical regions. Colonial expansion had enabled Europeans to grow indigo plants commercially in their overseas possessions and three major powers had been successful in supplying the European market with the dye. Spain imported indigo largely from Guatemala, El Salvador, and southern Mexico; ${ }^{\mathrm{I} 4}$ France from Haiti ${ }^{15}$ and Britain from its southernmost colonies in North America. Each country would then sell part of their indigo profitably to other European regions. These three American systems collapsed around the same time but for different reasons. Plant disease and war decimated Guatemalan exports, the American Revolution blocked indigo exports to Britain, and the Haitian Revolution wrecked indigo production there. ${ }^{\mathrm{I}}$

14. Under Spanish rule this entire region was part of the Captaincy General (or Kingdom) of Guatemala and the indigo it produced was generally known as "Guatemala" or "Guatimala". I5. Then known as Saint-Domingue.

I6. Willem van Schendel, "The Asianization of Indigo: Rapid Change in a Global Trade Around I 800", in Peter Boomgaard, Dick Kooiman, and Henk Schulte Nordholt (eds), Linking Destinies: Trade, Towns and Kin in Asian History (Leiden, 2008), pp. 29-49. 
These crises occurred at a time when the European demand for indigo was increasing, so soon efforts were afoot to supply indigo from new tropical locations. The British eyed their new possession, India, and not much later the Dutch began to experiment in Indonesia. French attempts to establish indigo in Senegal and Spanish attempts in the Philippines and Venezuela came to nothing, largely because of ecological miscalculations and problems of labour supply. ${ }^{17}$ Before long Asia provided the bulk of indigo to Europe, with India far outstripping Indonesia.

This move from American to Asian systems implied an important shift in labour relations. The American systems had been based on a separation of land and labour. Here forced - mostly slave - labour produced indigo on European-owned plantations. ${ }^{18}$ Initially, this plantation model was tried in Asia but it failed. ${ }^{19}$ The reasons for the failure were related to the foundations of colonial power in Asian societies.

\section{THWARTING CAPITALIST AGRICULTURE IN BENGAL}

In the closing decades of the eighteenth century British India was a new colony, expanding from its bridgehead in Bengal. Its survival and expansion depended on a steady income from the densely populated countryside. The British had inherited a sophisticated system of land taxation. Customarily peasant cultivators were in hereditary possession of plots for which tax was individually assessed. Landlords had hereditary

17. George Hardy, La mise en valeur du Sénégal de 1817 à 1854 (Paris, I92I); Frédérique Langue, "El añil en la Venezuela illustrada: una historia inconclusa", Revista de Indias, 58:2 I 4 (1998), pp. 637-653.

18. In Haiti and in the British colonies in North America indigo was produced largely by means of slave labour. See Gabriel Debien, "Une indigoterie à Saint-Domingue à la fin du XVIIIe siècle", Revue de l'Histoire des Colonies Françaises, 28-34 (1940-1946), pp. I-49; John Garrigus, "Blue and Brown: Contraband Indigo and the Rise of a Free Colored Planter Class in French Saint-Domingue", The Americas, 50 (1993), pp. 233-263; Virginia Gail Jelatis, "Tangled up in Blue: Indigo Culture and Economy in South Carolina, I747-1800" (Ph.D. dissertation, University of Minnesota, 1999). In the indigo-producing parts of Spanish Central America (now El Salvador, Guatemala, and Mexico) it was both African slaves and conscripted locals who provided labour to the crop. See Robert S. Smith, "Forced Labor in the Guatemalan Indigo Works", The Hispanic American Historical Review, 36 (1956), pp. 319-328; Thomas Fiehrer, "Slaves and Freedmen in Colonial Central America: Rediscovering a Forgotten Black Past", Journal of Negro History, 64 (1979), pp. 39-57; and David McCreery, "Indigo Commodity Chains in the Spanish and British Empires, I 560-1860", in Steven Topik, Zephyr Frank, and Carlos Marichal (eds), From Silver to Cocaine: Latin American Commodity Chains and the Building of the World Economy, I 500-2000 (Durham, NC [etc.], 2006), pp. 53-75.

19. Cf. Carel Blume, "Short Sketch of the Measures adopted for the introduction of Indigo and the promotion of Agriculture in Bengal between the Year I779 \& I790", 30 December 1790, Home Department, Miscellaneous/434, 599-617, West Bengal State Archive, Kolkata. See also Peter J. Marshall, "Private British Investment in Eighteenth-Century Bengal", Bengal Past and Present, 86 (1967), pp. 52-67, 60. 
rights to receive rent from the peasantry on their (usually extensive) estates and were bound to pass some on to the state. Therefore, landlords (zamindars) acted as tax collectors but did not own all land rights.

Early British administrators attempted to manipulate this pre-colonial system, notably by raising tax demands and curtailing cultivators' rights. The ecological, economic, and political results were disastrous. An enormous famine and peasant rebellions prompted the colonial government to reconcile itself to the impossibility of dislodging the old system. The hereditary land rights of cultivators/tenants were safeguarded under the zamindari system (or Permanent Settlement), which became the core of colonial control in 1790 and would survive, with minor adaptations, until the 1950 . ${ }^{20}$

This stability came at a price. Nothing was allowed to undermine the system and rural enterprise could flourish only within its confines. For this reason Europeans were not allowed to settle in rural areas without government permits, which were hard to get. This restriction posed a serious barrier to indigo production by Europeans because ecological constraints made this a rural industry. Indigo plants had to be processed within hours of being harvested and their treatment required large amounts of clean water, so indigo factories had to be close to the fields. With European investors keen to exploit the opportunities that Bengal offered - the world's best export variety of indigo (Indigofera tinctoria) is native to the region - an uneasy compromise was reached. Selected Europeans were allowed to reside and set up factories in rural areas but not to own indigo lands. Therefore plantations could not develop and the standard term for these factory managers - "indigo planter" - was a misnomer: they did not grow indigo but depended on their ability to entice, cajole, or force cultivators and their landlords to grow indigo. Cash advances and physical force were the two main instruments to ensure the supply of raw material to the factories.

These instruments worked well in Bengal, which turned out to provide a combination of climate, soil, and water supply that was exceptionally favourable to indigo cultivation. As a result, the indigo industry spread astonishingly fast and, for over a century, millions of cultivators would grow indigo plants and hundreds of thousands of labourers would work in thousands of indigo factories in rural Bengal and adjacent provinces of British India. $^{2 \text { I }}$

20. Sugata Bose, Peasant Labour and Colonial Capital: Rural Bengal since 1770 (Cambridge, 1993).

2 I. For more detail, see Willem van Schendel, "Green Plants into Blue Cakes: Working for Wages in Colonial Bengal's Indigo Industry", in Marcel van der Linden and Leo Lucassen (eds), Working on Labor: Essays in Honor of Jan Lucassen (Leiden [etc.], 20I2), pp. 47-73. The term "Bengal" needs some clarification because over time it has referred to different geographical entities. Here I use it to 


\section{INDIGO LABOUR IN BENGAL}

How can we analyse the labour relations of this "agrarian system"? Following the distinction outlined above, let us first look at cropping. Indigo is a fast-growing plant. In the extremely fertile soil and humid, hot climate of Bengal it took three months from seed to harvest, after which cultivators usually planted other crops. Indigo was labour-intensive because it required multiple rounds of ploughing and weeding. It was also a risky crop: yields were unpredictable both because floods could destroy the plants and because the dye content of indigo leaves cannot be gauged on the field but only during further stages of processing. Field labour was provided by household members - usually men and boys because women were barred from ploughing, and in many areas did not work in the fields at all. When necessary, wage labourers were employed during peak times but the local supply of labour was not plentiful. ${ }^{22}$ Peasant cultivators were both custodians of indigo-growing knowledge and providers of field labour - they controlled the cropping phase.

Indigo field labour was embedded in a local "activity system". The production units - rural households - came in many forms, from subnuclear to multi-generational. As a result, there was considerable variety between households but all were pluriactive. The "activity system" included food crops, with rice being a priority, followed by pulses, vegetables, spices, and many subsidiary crops. Unlike indigo, these required on-farm processing, storage, and preparation for home consumption or the market. The "activity system" also included livestock rearing (most commonly chickens, goats, and cattle). Crop processing and livestock rearing were mostly women's work. Many households caught their own fish and were involved in small trade at local markets that assembled every three days. Some households provided village services such as carpentry, blacksmithing, health care, or the priesthood. In other words, indigo cultivation competed with many other activities, so decisions about the allocation of household labour required a careful weighing of anticipated benefits.

Stepping back from the level of the production unit, the complexities of the "agrarian system" come into view. The introduction of indigo as a cash crop made new demands on the social structure in which the

denote what in colonial times was known as Bengal Proper or Lower Bengal, roughly today's Bangladesh and West Bengal (India).

22. Cf. "Report on the Conditions of the Lower Classes of Population in Bengal", Calcutta, I 888, British Library. This report is also known as the Dufferin Report. For details of this report, see the analysis in Willem van Schendel and Aminul Haque Faraizi, "Rural Labourers in Bengal, I880 to 1980", Comparative Asian Studies Program (CASP), Erasmus University Rotterdam, 1984 . 


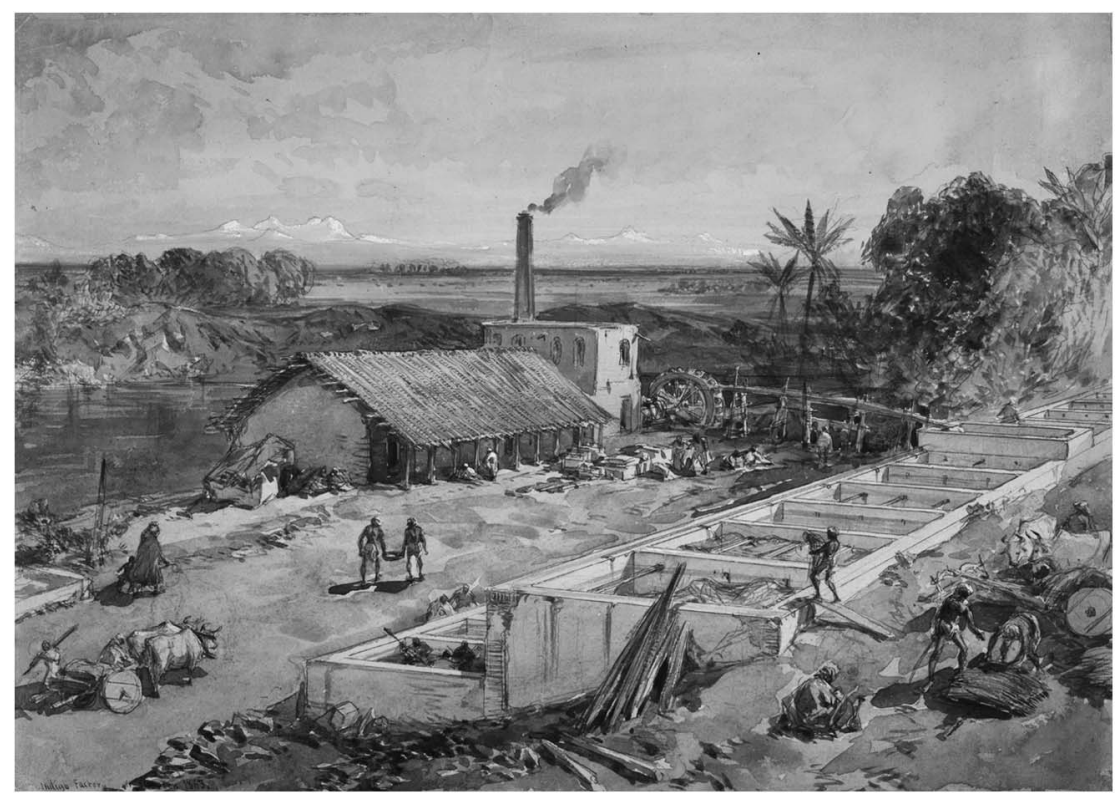

Figure 2. An indigo factory in rural Bengal; watercolour by William Simpson, I863. (C) British Library Board. Used with permission.

exploitation of land was embedded. Indigo displaced other activities and introduced new labour demands. Its main innovation was the creation of an entirely new set of labour relations in the countryside. ${ }^{23}$ Whereas field labour was accommodated within existing labour relations, the establishment of indigo processing plants (indigo factories) demanded new ones. The factories needed labour to transport the leaves, carry out the numerous work processes in the factory, and despatch cubes of dye to the port of Calcutta (Figure 2). These agro-industrial labour relations were part of the "agrarian system", even though they were not cropping.

Many rural households became deeply involved in indigo processing. Some of these were the same households that grew indigo, especially those who owned the boats or ox-carts that transported leaves to the factory. But very few offered their labour to the factories. Local peasants felt no need to work for wages as low as those offered by the factories, preferring to cultivate their own fields or those of others. Therefore, it was migrants who supplied most factory labour. Different groups of

23. It has been said that, in rural colonial India, indigo companies were the first large organizations to operate that were not military or religious in nature; Raaj Sah, "Features of British Indigo in India", Social Scientist, 9:2/3 (1980), pp. 67-79, 69. 
migrants filled different positions in the complex processes that turned indigo leaves into dye, and many came from far away. For example, common labourers ("coolies") were from the hills of Chhota Nagpur in central India, hundreds of kilometres distant. They travelled in wellorganized labour gangs, usually returning to the same factory during the processing season year after year. ${ }^{24}$ There were also specialized labourers masons, carpenters, horsemen, house servants, and the factory militia - many of whom came from north India. The office and managerial staff was from different parts of British India, and the manager usually came from Europe or the Caribbean. ${ }^{25}$ Bengal indigo factories were multicultural and multilingual spaces; link languages were Hindustani, English, and Bengali.

Thus the "agrarian system" of indigo production in Bengal included labour relations of different kinds. Household labour dominated the agricultural sphere and wage labour the agro-industrial sphere. Some households participated in both but for most there was a clear distinction. To understand the dynamics of indigo production it is essential to look at these spheres together.

Although most cultivators freely entered into agreements with factory managers to grow indigo for the factory, a system of advances made it very difficult for them to extract themselves from the relationship. As the remuneration for indigo was low, many soon considered it an unattractive crop and preferred to switch household labour to other activities. ${ }^{26}$ Landlords, keen to maximize their income from the peasantry, often supported the cultivators. Inevitably tensions built up, with peasants and their landlords pitted against factory managers. This prompted managers to employ extra-economic coercion, notably the legal system and brute force. The latter was illegal but very effective. Indigo factories had their own armed forces and jails, in which they meted out punishment to uncooperative cultivators. ${ }^{27}$ As a result of these tensions, the "agrarian system" was riddled with conflict over the allocation of peasant labour. Indigo became closely associated with a range of peasant uprisings and their bloody suppression. ${ }^{28}$ By contrast, labour relations in the indigo factories were relatively peaceful and factory labourers did not join in peasant protests against the "indigo devil".

24. Cf. S.T. Cuthbert, "Extracts from a Report on Chota Nagpore", Journal of the Royal Asiatic Society of Great Britain and Ireland, 8 (I846), pp. 407-4I6, 4I3.

25. Cf. Thomas Machell, "Journals of Thomas Machell" (I840-1856), Vol. 2. India Office Private Papers, Mss Eur B 369 , British Library.

26. Cf. Report of the Indigo Commission, I860: Report, Minutes of Evidence and Appendix (Calcutta, I 860-I 86I), passim.

27. Cf. A Ryot, Selections from Papers on Indigo Cultivation in Bengal, with an Introduction and a Few Notes (Calcutta, I 858).

28. Blair B. Kling, The Blue Mutiny: The Indigo Disturbances in Bengal, I859-1862 (Calcutta, 1977); Report of the Indigo Commission, I860. 


\section{FORCED CASH-CROPPING IN JAVA}

In Java the Dutch faced circumstances that differed from the Americas in ways that seem at first glance to have been similar to circumstances in Bengal. Here, too, the dominant American model - plantations run by a slave workforce - could not be emulated because peasant producers occupied the land. ${ }^{29}$ But historically the Javanese "agrarian system" had developed quite differently from that of Bengal, and this shaped the introduction of indigo.

Although both Bengal and Java had tropical climates and fertile soils, these had different implications for indigo cultivation in each place. Java's climate was more predictable because it lacked Bengal's variation in summer floods and monsoon rains; this made indigo yields in Java more reliable. But Java lacked Bengal's huge expanse of deltaic land with annual deposits of new silt that allowed for easy rain-fed cultivation on level fields surrounding cultivators' homesteads. Many parts of Java were mountainous and cultivators had to travel longer distances to their fields. This was a disadvantage in the case of indigo. Whereas cultivators in Bengal could load their harvested indigo on river boats, or use ox-carts on level roads, in Java indigo had to be carried by yoke or ox-cart over bad mountain roads and over much longer distances to reach the indigo factories.

This natural disadvantage interacted with a specific land system to make Java indigo much less of a commercial success story than Bengal indigo. In Java land ownership was not individualized as it was in Bengal, where estate-holding landlords collected state taxes from hereditary tenants. In Java the relationship of the peasantry to the state was mediated through village headmen who seasonally distributed communal village lands to cultivators and in return extracted labour rather than cash taxes from them. Each household was required to perform labour service on communal

29. In the Americas indigo was primarily produced by slave labour but not all local systems worked in the same way. The US and Haiti featured a classic colonial plantation system with African slave labour, but the labour employed in "Guatemala" indigo (produced in El Salvador, Guatemala, and southern Mexico) was a mix that changed over time. In response to steep population decline, the colonial government had prohibited the employment of indigenous labour, so indigo was cultivated and processed by African slave labour, which proved too expensive, and free mestizo and mulatto labour, which proved too hard to discipline. As European demand for indigo grew, entrepreneurs pressed for more and cheaper labour. As a result, forced indigenous labour was introduced under the repartimiento system, which shared some features with the system that later developed in Java but also differed from it, for example, in terms of wage payments, size of production units, and European entrepreneurial dominance. See Smith, "Forced Labor in the Guatemalan Indigo Works"; Munro J. MacLeod, Central America: A Socioeconomic History, I 520-1720 (Berkeley, CA [etc.], I973), pp. I84-193; Manuel Rubio Sanchez, Historia del añil o xiquilite en Centro America (San Salvador, 1976); and José Antonio Fernandez Molina, "Colouring the World in Blue: The Indigo Boom and the Central American Market, 1750-1810" (Ph.D. dissertation, University of Texas at Austin, 1992). 
fields retained by the village head in addition to the labour it employed on the fields assigned to it. The state extracted surplus from the heads in the form of produce or cash.

The colonial government in Java, like its counterpart in Bengal, was vitally concerned with its income from land. In Java, as in Bengal, Europeans were not free to settle in the countryside and could do so only with government permission. But whereas the Bengal authorities allowed private entrepreneurs to ease themselves into the agrarian order and seek accommodation with landlords and peasants, from the I 820 s the authorities in Java steered a very different course. Before that, however, there was for a short period a direct link between government policy in Bengal and Java. In I8I I, after France had invaded the Netherlands, the British took over the Dutch East Indies and encouraged indigo entrepreneurs from Bengal to settle in Java. The Dutch returned in I8I6 and countenanced private (mostly European) indigo enterprise but they were not happy with its dubious results.

Things changed dramatically in 1830 when they overhauled their agrarian policy with a view to making Java a more remunerative colony. The new "cultivation system" (Cultuurstelsel) harnessed the customary system of rural labour services to produce export crops for the European market. Indigo was the first crop to which this policy of forced cultivation was applied. After some experimentation the authorities settled on a scheme of extreme dispersion. In their view, the environmental and social conditions of Java made processing of indigo in large factories impractical and expensive. So they ordered indigo leaves to be processed in tiny local factories managed by village heads. This decision produced labour relations that took a locally specific form.

\section{INDIGO LABOUR IN JAVA}

The distinction between "cropping system", "activity system", and "agrarian system" facilitates analysis of the labour relations that developed under the cultivation system. The government ordered a village to produce a certain amount of indigo and the village head put villagers to work on communal land in order to meet this demand. Cropping was the domain of household labour who were forced to act as unpaid indigo growers. The custom of labour service to the village head served as an ideological umbrella, but the high government demand required the introduction of a far more exploitative system, leading to new forms of resistance and evasion. The crop demanded careful tending and the cultivators were made to work extremely long hours. Even so, foot-dragging often resulted in mediocre or poor harvests.

The reasons for the low standard of cropping are obvious when we consider the "activity system". Cultivators were made to work so intensively 
on the export crop that they were forced to abandon other activities that were essential to their survival. $3^{\circ}$ These included the production of food crops, wage labour, and petty trade. In addition, they were forced to add another task to their activities: carrying head-loads of indigo leaves to the factories, which could be far away. "Government indigo" became a crop that cultivators hated because it distorted their "activity system".

But this was not the only level on which the cultivation system intruded. Labour relations in the "agrarian system" were also affected. The authorities phased out private indigo factories and allowed only government-controlled ones. But they worried about the investments they had to make to run these factories - mainly construction and maintenance costs, indigo-makers' wages, and supervision. Then they hit on the idea of having village leaders establish very small factories near the fields and making the villagers responsible for running them. ${ }^{31}$ The government provided loans for their construction, which had to be paid back in indigo. Management, maintenance, and production costs had to be borne by the village heads, whose hands were strengthened vis-à-vis the other villagers. The government now merely had to pay an itinerant inspector to oversee the quality of indigo produced in a number of these village factories. Indigo of sufficient quality was counted against the tax demand settled on the village. As a result, forced labour was now extended from the fields to the factories, and households had to supply unpaid labour to the village factory.

Thus, the "agrarian system" that produced indigo was based on forced labour. Under the cultivation system the customary labour services, which Javanese villagers had been required to supply to their village head, were extended from the "cropping system" to the "activity system", and beyond that to the "agrarian system". Wage labour, which had been a sizeable source

30. According to one source: "In some districts the population worked the indigo fields for entire months without getting any wages. There were villages in the district of Simpoer whose inhabitants had been incessantly engaged in that labour and had had to provide for their own food, and when they returned home, they found their paddy crop ruined for lack of care [...] there are numerous examples of women big with child who gave birth during heavy labour in the indigo fields, or of planned marriages that were celebrated there [in the fields] because nobody was allowed to go home. It had become a popular saying: Penganten di tarum, boenting di tarum, anak tarum [wedding in indigo, pregnant in indigo, children in indigo]." See Blik op het Bestuur van Nederlandsch-Indië onder den Gouverneur-Generaal Js. van den Bosch, voor zoo ver het door denzelven ingevoerde Stelsel van Cultures op Java betreft [...] (Kampen, I835) [attributed to Pieter Merkus], pp. 53-55.

3 I. In the words of the administrator promoting these village factories: "The chief aim of establishing small indigo factories was to relieve the population of the duty to work at great distances from their villages, and to make them enjoy the advantages not just of the cultivation, but also of the manufacture [of indigo]." See J.B. Elias, "Inrigting en Verdeeling der Werkzaamheden bij de Kleine Indigo-Fabrijken", Buitenzorg, 26 March I 834, in Besluiten van den Gouverneur-Generaal ad Interim van Nederlandsch Indië, 28 Maart I 834. 
of supplementary income for many village households, was marginalized as household labour was commandeered for compulsory cash-crop production.

Cultivators clearly resented this but had little opportunity to resist. The cultivation system proved to be a well-oiled machine because the village elite supported it: they were given more government support and income and therefore more power over their fellow villagers. As agents of state policy they could embed the stepped-up demands in a cultural idiom that was traditional - the well-established right of village heads to labour services in return for distributed land. Caught in this web, many peasants endured the new system. ${ }^{32}$ Others, however, employed an old strategy of evasion: moving away from fields that were designated for indigo production, which the relative profusion of cultivable land in Java made possible at the time. ${ }^{33}$ Only in a few cases, cultivators turned violently against indigo. ${ }^{34}$

\section{TWO “AGRARIAN SYSTEMS”: BENGAL AND JAVA}

British and Dutch colonialists were convinced of the profitability of initiating export indigo production in their Asian possessions. Embedding these new commodity chains proved to be complicated, however. They could not employ the agrarian business model of the day - the slave-run American plantation - and had to feel their way towards a new model. They soon realized that such a model needed very fine local tuning. The pre-colonial "agrarian systems" of Bengal and Java were more resilient than the American ones had been; they could not be swept aside or easily manipulated. It soon became evident to the colonial rulers that Asian monsoon climates, soils, and water supplies set definite limits on what could be achieved - and that the problems presenting themselves in Bengal and Java differed considerably. They had to fathom the intricacies of these divergent eco-agrarian orders.

Let us revisit the three nested systems for a simple comparison. The "cropping systems" in Bengal and Java were fairly similar but by no means identical. Both regions had a tropical monsoon climate but with

32. For example, around I 840 two-thirds of the cultivators in Cirebon Residency grew indigo; Merennage Radin Fernando, "Peasants and Plantation Economy: The Social Impact of the European Plantation Economy in Cirebon Residency from the Cultivation System to the End of the First Decade of the Twentieth Century" (Ph.D. thesis, Monash University, I982), p. I 28. 33. Fernando, "Peasants and Plantation Economy", p. I 30 . Also cf. S. van Deventer, Bijdragen tot de Kennis van het Landelijk Stelsel op Java, op Last van Zijne Excellentie den Minister van Koloniën, J.D. Fransen van de Putte [...] (Zalt-Bommel, I865), III, p. I24; Blik op het Bestuur, pp. $76-77$.

34. The Cirebon Troubles of December 1830 could be traced to excessive oppression of cultivators forced to produce indigo for export. Cf. Van Deventer, Bijdragen, II, pp. 195-I96, 3 10-3 16. See also Marijke Hemker, "Het Kultuurstelsel op Java getoetst aan de indigokultuur in Pekalongan, I830-1859" (M.A. thesis, University of Amsterdam, I98 I), pp. 94-97. 
considerable local variation. Soil conditions, agricultural cycles, and cropping combinations showed differences as well. Even the indigo plants were not of exactly the same species - and yet they yielded the same dye. The labour relations that exploited these agronomic idiosyncrasies were, however, quite similar. In both cases it was household labour using basic technology that nurtured the crop, occasionally supplemented with wage labour.

It was at the level of the "activity system" that disparities in labour relations revealed themselves more clearly. In Bengal the indigo cultivators had more freedom. They were bound to indigo cultivation by indebtedness to private entrepreneurs rather than by forced labour service backed up by the state, as in Java. And they could, and sometimes did, disentangle themselves. In their struggles they had powerful protectors: landlords were keen to curb the power of indigo entrepreneurs if these encroached on their interests. Bengal landlords were in favour of tenants cultivating food and other crops, if these fetched higher prices in the market. Like the indigo factories, landlords employed groups of armed men, and these would fight those hired by factory managers, leading to frequent brawls and altercations. All this was starkly different in Java, where the village elite controlled indigo cultivation on designated fields and worked the population so hard that there was little time for other crops. Moreover, in Bengal indigo was grown largely as a seasonal crop, freeing labour for other crops, trade, and wage labour during the rest of the year. In Java indigo was harvested several times a year to keep the factories going and yield as much government tax value (and income for the village elite) as possible. As a result, Bengal peasants could maintain a richer "activity system" than their counterparts in Java.

A comparison of labour relations in the "agrarian system" shows up even greater divergence. In Java labour relations beyond the peasant production unit were a negligible part of indigo production. Basically, the only non-peasant labour that was required here was the salaried inspector of village factories and the carters who transported chests of the finished product, indigo cubes, to the government storehouse in Surabaya. The cultivation system succeeded in extending unpaid peasant household labour to industrial production. This was possible only because the Javanese peasantry had weak land rights, the tax demand was householdbased rather than plot-based, and rural elites benefited from the new system and allied themselves with the state.

In the "agrarian system" of Bengal, however, labour relations beyond the peasant production unit were crucial. Indigo could not have been produced without massive inputs of waged labour. The large indigo factories ran entirely on paid labour and there was an intricate order of wages connected with the various stages of processing and dye-making. ${ }^{35}$ 
Even though resident peasant households were not keen to provide labour to the factories, industrial dependence on wage labour never became a problem. The indigo factories could benefit from seasonal rural migration circuits that had long linked Bengal to north India as well as from new migration flows from central India that resulted from impoverishment under colonial rule. These migrants were willing to work for low wages, keeping the costs of dye production low and minimizing the need for technological innovation in the indigo industry.

The "agrarian system" in Bengal had its own problem, however: it was inherently unstable. There was a poor fit between the interests of the four main parties - cultivators, landlords, indigo factory managers, and the state - and the system needed constant adjustment. ${ }^{36}$ There were two sets of labour relations that were especially unstable. First, the managers needed to ensure a steady flow of fresh indigo leaves to their factories at the right time. They had to coerce the many cultivators who did not wish to grow indigo. Usually monetary incentives sufficed: advances turning into permanent indebtedness. There was little risk of cultivators running away because, unlike their Javanese counterparts, most had individual hereditary (and non-saleable) rights in land. But in Bengal peasants could be obstreperous, especially when landlords, preferring their tenants to apply their labour to other crops, backed them up. Resistance could take the form of judicial action - rural Bengal was notoriously litigious - or physical confrontation. ${ }^{37}$ Despite being often embroiled in lawsuits and affrays, the indigo industry's two methods, credit and strong-arming, did usually deliver fresh indigo to the factory doorstep. It was only during periods of large-scale peasant revolt that industrial production suffered.

A second instability resulted from the fact that indigo production in Bengal depended on speculative investment by (mostly British) shareholders who owned the indigo companies and the "agency houses" that managed the factories - and they expected quick returns. These investments paid the factory managers' basic salaries (which, in good years, were amplified with bonuses in proportion to output) but market fluctuations, bankruptcies, and steep shareholder demands continuously disrupted the industry. ${ }^{38}$ Companies would go bust, causing their dispersed

36. This is one of the main themes running through the volumes of Thomas Machell's "Journals".

37. For example, see Copies of the Circular Letters Sent on the I3th and 20th of July I 810 by Orders of the Governor General in Council of Fort William to the Magistrates under that Presidency; Ordered, by the House of Commons, to be printed, 27th April I813 (London, I81 3); Report of the Indigo Commission, I860.

38. S.B. Singh, European Agency Houses in Bengal (I783-I833) (Calcutta, 1966); Marshall, "Private British Investment in Eighteenth-Century Bengal"; Amales Tripathi, Trade and Finance in the Bengal Presidency, I793-I833 (Calcutta, 1979); Tony Webster, The Richest East 
factories to shut down or be sold to competitors. Factory managers would be dismissed if they did not produce the hoped-for amount of dye, or they would give notice if forced to apply even more excessive methods on the peasantry. And competitors lured the most productive managers with higher salaries. In other words, labour relations at the managerial level were volatile.

These instabilities were magnified by climate variation, which was much greater in Bengal than in Java. Seasonal rains were difficult to predict and a drought could wipe out the rain-fed crop. Summer floods were an annual hazard. When the huge Ganges and Brahmaputra rivers breached their banks, the deltaic countryside would suffer shallow or deep flooding. The unpredictability of the yield increased the instability of an "agrarian system" already subverted by the coercive and contested character of indigo cultivation and the voracity of faraway shareholders.

\section{THE FADING OF INDIGO}

We have seen how the embedding of export indigo in two Asian "agrarian systems" created distinct sets of local labour relations. Importantly, the labour relations that indigo forged here had a longer lifespan than the crop that gave rise to them.

In Bengal the heyday of commercial indigo was from the I 790 s to the I860s, when large-scale rebellions, jointly known as the Nil Bidroho (Indigo Revolt or Blue Mutiny), broke its back. ${ }^{39}$ Some indigo continued to be produced here but most factories were forced to close down. The industry moved to northern regions (Bihar, United Provinces) where it survived for another forty years. ${ }^{\circ}$ Significantly, the large-scale indebtedness that indigo had introduced in the Bengal countryside continued to be a powerful mechanism to extract new crops from peasant households notably jute - but violent coercion would never be as important as it had been under indigo.

In Java, indigo boomed for a shorter period, from the late 1820 s to the I 85 os. During the final years of the cultivation system (which lasted until I 870) indigo was gradually replaced by other cash crops, such as sugar, tea, and coffee. The forcing of labour that had been so effectively experimented with in indigo survived in other cash crops till the end of the cultivation system, which was abolished less for economic than for political reasons.

India Merchant: The Life and Business of John Palmer of Calcutta, 1767-I836 (Woodbridge, 2007).

39. Kling, Blue Mutiny.

40. By 1900 German-made synthetic indigo dye began to flood European markets; it soon destroyed the export markets for natural indigo. 


\section{CONCLUSION}

Scholars of the French school of comparative agriculture developed the concept of the "agrarian system" to connect scales of analysis in the study of rural societies and to understand "agricultural developments throughout history, including those [developments] sometimes interpreted in terms of 'crises' or 'agricultural revolution'".$^{4 \mathrm{I}}$ It is an approach that seeks to tack between different perspectives (from agricultural practices in the "cultivated ecosystem" 42 to global social relations); between moments in time (for example, the succession of "agrarian systems"); and between disciplinary approaches (from the biophysical to the socio-political). Its main ambition is to bridge the gap between technical approaches such as farming-systems research and social approaches such as peasant studies. It joins other recent initiatives, for example political ecology and environmental history, in offering a "systemic approach to productive processes combined with a deep understanding of their relationship to social processes throughout time". ${ }^{43} \mathrm{It}$ distinguishes itself from these other approaches, however, by its spatial imagery and its emphasis on scale.

In this article I have employed the concept to explore its utility as a conceptual tool, especially to distinguish analytically between agricultural labour and agrarian labour. My examples show how a new export crop, indigo, restructured rural labour relations in two Asian societies well beyond the agricultural sphere. At the same time, however, these cases indicate that colonial administrators and entrepreneurs found the preexisting agrarian orders in these Asian societies far less malleable than those in North and Central America. Certainly, technical knowledge of indigo (and some managerial personnel) travelled fairly easily from the Americas to Asia, as witness the many indigo manuals that were translated and published for readers in Asia. ${ }^{44}$ Matching this knowledge with the peculiarities of the "cropping systems" of Bengal and Java required fine-tuning but - unlike in other colonies in which they attempted to

41. Cochet, "The Système Agraire Concept”, p. I35.

42. Mazoyer and Roudart, A History of World Agriculture, p. 48.

43. Cochet, "The Système Agraire Concept", p. I 34.

44. Among the most influential manuals were M. de Beauvais Raseau, L'Art de l'Indigotier (Paris, 1761), English translation: M. de Beauvais Raseau, Treatise on Indigo, tr. Richard Nowland (Calcutta, 1794)); Élie Monnereau, Le Parfait Indigotier: on Description de l'Indigo. Nouvelle Édition [...] augmentée par l'auteur (Amsterdam [etc.], 1765), English translation: Elias Monnereau, The Complete Indigo-Maker, Containing an Accurate Account of the Indigo Plant [...] (London, 1769); Joseph-François Charpentier de Cossigny, Essai sur la fabrique de l'indigo (Isle de France, I779), abridged English translation: Joseph François CharpentierCossigny de Palma, Memoir containing an abridged treatise on the Cultivation and Manufacture of Indigo [...] (Calcutta, I789); José Mariano Moziño Suárez de Figueroa, Tratado del xiquilite $y$ añil de Guatemala (Guatemala, I797, repr. with added notes Manila, I826). 
embed indigo - it proved thoroughly achievable here. ${ }^{45}$ It was far more difficult, however, to fit indigo into the "activity systems" and "agrarian systems" of these regions.

There were interlocking reasons for this. First, pre-colonial arrangements had produced tight-knit rural orders. In both Bengal and Java powerful rural elites had distinct claims on the land and played pivotal roles in tax collection for the state. In Bengal, these were landlord-tax collectors (zamindars) and in Java village heads. These elites were not all-powerful, however: cultivators had clearly recognized claims on the land as well. In Bengal they were in hereditary possession of plots whose tax was individually assessed. In Java they were entitled to customary (re)distribution of cultivation rights over plots of land. The interests of these two rural classes - elite and cultivators merged thus in a plot-oriented, tax-moulded rural order.

Second, the two colonial states made themselves so dependent on the taxation systems, which they had inherited, that an overhaul - and the wholesale removal of pre-colonial rural elites - was out of the question. This implied that the land could not be cleared of previous occupants (as had happened in many places in the Americas) and that cash-cropping could not take the form of capitalist agriculture in the shape of plantations worked by slaves or wage labourers. Instead it had to be embedded in the pre-existing "activity systems" and "agrarian systems". In this way, the colonial state was assured of both tax income and export crops but it found itself embroiled in "agrarian systems" that were difficult to read and handle.

This comparison shows that the notion of the "agrarian system" can be of considerable value. In the examples considered it has allowed us to analyse agrarian labour relations across a temporal divide (as Bengal and Java transformed from pre-colonial to colonial orders) and two locations (the insertion of a single export crop in these societies producing quite different outcomes in terms of labour relations). Importantly, this approach

45. Local observers sharing their knowledge did much of this fine-tuning; for example PierrePaul Darrac, "De la Culture de l'Anil et de la fabriquation de l'Indigo au Bengale (I 823)", Mss Eur Fi93/87, British Library, (for an introduction and translation, see Pierre-Paul Darrac and Willem van Schendel, Global Blue: Indigo and Espionage in Colonial Bengal (Dhaka, 2006); H. Piddington, "On the Manufacture of Indigo" (1829), Transactions of the Agricultural and Horticultural Society of India, Vol. 2 (I836), pp. 24-29; J.E. de Sturler, "Indigo-cultuur en vervaardiging" [4 August I829], Indisch Magazijn, 2:1 I-I 2 (1845), pp. 55-60; and Ament, "Bereiding en Kultuur der Indigo op Java" (I834), in De Cultuur en Bebandeling der Westindische Koffij en Indigo, Beschreven en Vergeleken met die der Zelfde Producten in Oost-Indië, Uitgegeven door de Redactie van den Oosterling (Kampen, I 836), pp. 17-42. It was only much later that the colonial states saw the need for scientific research into indigo. See Prakash Kumar, "Plantation Science: Improving Natural Indigo in Colonial India, I860-1913", British Journal for the History of Science, 40 (2007), pp. 537-565; Prakash Kumar, Indigo Plantations and Science in Colonial India (Cambridge, 20I2). Also cf. F.Ph. van Suchtelen, De toestand der tegenwoordige indigocultuur (Semarang, I888); and Indigo Proefstation Midden-Java (Semarang, I888). 
counteracts mono-causal explanations of labour relations, for example in terms of agro-environmental determinants, the force of colonial capitalism, or local work cultures. The "agrarian-systems" approach invites us to consider factors operating simultaneously on different scales. As we have seen, in Bengal and Java it was mixtures of local and non-local forces that moulded agrarian relations - and these forces were agronomic, environmental, infrastructural, administrative, military, and commercial in character. The combination and impact of such factors is not predetermined but must be investigated empirically.

The three scales - "cropping system", "activity system", and "agrarian system" - jointly provide a practical tool to assess and explain the differential distribution of such factors and to show their dynamism over time. And yet the "agrarian system" is a scale that needs further refinement. It accommodates forces beyond the locality and the region, and this is an essential plus, but it still lacks procedures to assess and rank the relative importance of such distant forces. Even so, this approach reminds us that the inclusion of non-human, environmental "agency" is key to a proper understanding of social transformations. The concept of the "agrarian system" is an effective expedient to promote agriculturesensitive readings of social transformations and to compare social orders that comprise both agricultural and non-agricultural labour relations.

\section{TRANSLATED ABSTRACTS \\ FRENCH - GERMAN - SPANISH}

Willem van Schendel. Qu'est-ce que le travail agraire Production contrastée de l'indigo dans l'Inde coloniale et en Indonésie.

Dans les écrits érudits, le terme de "travail agraire" est utilisé avec divers sens. Il peut se référer à un ensemble très spécifique d'activités productives - la culture de récoltes et l'élevage de bétail - mais il peut également avoir la connotation beaucoup plus large de travail rural ou non-urbain. Ces différents usages peuvent porter à confusion, particulièrement dans la recherche comparative. Ce article part de l'École française d'agriculture comparée, et sa conceptualisation de trois échelles d'analyse imbriquées - le "système de culture", le "système d'activités", et le "système agraire". Il met à l'épreuve ces idées dans une comparaison de la main d'œuvre employée dans la production de l'indigo dans deux systèmes coloniaux (l'Inde britannique et les Indes orientales néerlandaises). L'article conclut que cette approche permet de contrecarrer les explications monocausales des relations de travail en termes de déterminants agro-environnementaux, de force du capitalisme colonial ou de cultures de travail locales. Il préconise également une lecture perspicace des transformations sociales, en comparant des ordres sociaux qui couvrent tant des relations de travail agricoles que des relations de travail non-agricoles. 
Willem van Schendel. Was ist agrarische Arbeit? Indigoproduktion im Vergleich zwischen dem kolonialen Indien und Indonesien.

In wissenschaftlichen Arbeiten wird der Begriff "agrarische Arbeit” auf unterschiedliche Weise verwendet. Er kann auf eine bestimmte Gruppe produktiver Tätigkeiten verweisen - Landbau und Viehhaltung -, aber er kann auch viel allgemeinere Konnotationen von ländlicher oder nicht-städtischer Arbeit haben. Diese unterschiedlichen Begriffsverwendungen können Verwirrung stiften, vor allem in der komparativen Forschung. Der Aufsatz geht von der französischen Schule der komparativen Agrarforschung und ihrer Konzeptualisierung dreier aufeinander aufbauender Analyseebenen aus: "Anbausystem", "Aktivitätssystem" und "Agrarsystem". Diese Ideen werden anhand eines Vergleichs des Arbeitseinsatzes in der Produktion von Indigo-Farbstoff in zwei Kolonialsystemen (BritischIndien und Niederländisch-Ostindien) überprüft. Der Aufsatz gelangt zu dem Ergebnis, dass dieser Ansatz dazu beiträgt, monokausalen Erklärungen der Arbeitsverhältnisse entgegenzuwirken, die auf landwirtschaftliche Umweltfaktoren, die Gewalt des kolonialen Kapitalismus oder lokale Arbeitskulturen rekurrieren. Außerdem stützt der Ansatz Interpretationen gesellschaftlichen Wandels, die landwirtschaftliche Dimensionen beachten, indem soziale Ordnungen verglichen werden, die sowohl landwirtschaftliche als auch nicht-landwirtschaftliche Arbeitsverhältnisse umfassen.

Übersetzung: Max Henninger

Willem van Schendel. Qué es el trabajo agrario? Contrastando la producción de añil durante el periodo colonial en la india y en indonesia.

En los escritos académicos, el término "trabajo agrario" se utiliza en varios sentidos. Por un lado, puede referirse a un conjunto de actividades productivas muy específicas - el cuidado de los cultivos y la ganadería - pero también, por otro lado, puede adquirir la significación mucho más amplia de trabajo rural o no urbano. Estos usos distintos pueden llegar a ser confusos, especialmente en la investigación comparativa. Este artículo parte de las propuestas de la escuela de Agricultura Comparada Francesa y su conceptualización de las tres escalas analíticas que encajan unas en otras - el "sistema de cultivos", el "sistema de actividades", y el "sistema agrario". En nuestro texto comprobamos las ideas expuestas realizando una comparación del trabajo empleado en la producción del tinte de añil en dos sistemas coloniales (la India británica y la Indonesia holandesa). El artículo concluye que esta aproximación ayuda a cuestionar las explicaciones monocausales de las relaciones de trabajo en términos de los determinantes agro-medioambientales, la fortaleza del capitalismo colonial o las culturas locales de trabajo. En el mismo sentido también plantea lecturas que prestan atención a aspectos agrícolas de las transformaciones sociales comparando órdenes sociales que comprenden tanto las relaciones de trabajo agrícolas como las no agrícolas. 